\title{
IMPACTS OF NATURAL DISASTERS ON HOUSEHOLDS AND SMALL BUSINESSES IN INDIA
}

Archana Patankar

NO. 603

December 2019
ADB ECONOMICS WORKING PAPER SERIES 


\section{ADB Economics Working Paper Series}

\section{Impacts of Natural Disasters on Households and Small Businesses in India}

Archana Patankar

No. 603 | December 2019
Archana Patankar (archana@greenglobe.co.in) is Founder Director of Green Globe Consultancy.

This paper was prepared as background material for the Asian Development Outlook 2019 theme chapter on

"Strengthening Disaster Resilience." 
(C) 2019 Asian Development Bank

6 ADB Avenue, Mandaluyong City, 1550 Metro Manila, Philippines

Tel +632 8632 4444; Fax +63286362444

www.adb.org

Some rights reserved. Published in 2019.

ISSN 2313-6537 (print), 2313-6545 (electronic)

Publication Stock No. WPS190617-2

DOI: http://dx.doi.org/10.22617/WPS190617-2

The views expressed in this publication are those of the authors and do not necessarily reflect the views and policies of the Asian Development Bank (ADB) or its Board of Governors or the governments they represent.

ADB does not guarantee the accuracy of the data included in this publication and accepts no responsibility for any consequence of their use. The mention of specific companies or products of manufacturers does not imply that they are endorsed or recommended by ADB in preference to others of a similar nature that are not mentioned.

By making any designation of or reference to a particular territory or geographic area, or by using the term "country" in this document, $A D B$ does not intend to make any judgments as to the legal or other status of any territory or area.

This work is available under the Creative Commons Attribution 3.0 IGO license (CC BY 3.0 IGO)

https://creativecommons.org/licenses/by/3.0/igo/. By using the content of this publication, you agree to be bound by the terms of this license. For attribution, translations, adaptations, and permissions, please read the provisions and terms of use at https://www.adb.org/terms-use\#openaccess.

This CC license does not apply to non-ADB copyright materials in this publication. If the material is attributed to another source, please contact the copyright owner or publisher of that source for permission to reproduce it. $\mathrm{ADB}$ cannot be held liable for any claims that arise as a result of your use of the material.

Please contact pubsmarketing@adb.org if you have questions or comments with respect to content, or if you wish to obtain copyright permission for your intended use that does not fall within these terms, or for permission to use the ADB logo.

Corrigenda to ADB publications may be found at http://www.adb.org/publications/corrigenda.

Note:

In this publication, "\$” refers to United States dollars.

The ADB Economics Working Paper Series presents data, information, and/or findings from ongoing research and studies to encourage exchange of ideas and to elicit comment and feedback about development issues in Asia and the Pacific. Since papers in this series are intended for quick and easy dissemination, the content may or may not be fully edited and may later be modified for final publication. 


\section{CONTENTS}

TABLES AND FIGURES

ABSTRACT

I. INTRODUCTION 1

II. EXTREME PRECIPITATION: EXPOSURE, VULNERABILITY, AND IMPACTS 1

III. METHODOLOGY AND DATA 3

IV. ASSESSING IMPACTS

A. Household Impacts

B. Impacts on Businesses 16

$\begin{array}{ll}\text { V. SUMMARY AND CONCLUSION } & 20\end{array}$

$\begin{array}{lc}\text { REFERENCES } & 23\end{array}$ 


\section{TABLES AND FIGURES}

\section{TABLES}

1 Research Questions, Methodology, and Data Sources 3

$2 \quad$ Profile of Surveyed Wards in Mumbai 6

3 Estimated Repair or Replacement Cost of Damage 8

$4 \quad$ Number of Admissions at Government Hospitals 10

5 Profile of Household in Surveyed Areas of Chennai 11

6 Households Affected by Cyclone Phailin 14

$7 \quad$ Impact of Cyclone Phailin on Agriculture 15

$8 \quad$ Impact Cyclone Phailin on Fisheries 15

9 Estimated Reconstruction Cost for Damage Caused by Cyclone Phailin 16

10 Damage Costs Faced by Typical Retail Businesses in Mumbai 17

$11 \quad$ Immediate Expenditure after Floods 18

12 Damage Costs to Handloom and Handicrafts Businesses 20

13 Damages Suffered by Small and Medium-Sized Enterprises 20

\section{FIGURES}

1 Socioeconomic Categories of Surveyed Families $\quad 7$

$2 \quad$ Indirect Impacts of Mumbai Floods $\quad 9$

3 Compensation as a Percentage of Total Damage Cost 10 


\begin{abstract}
Extreme precipitation and flooding cause large-scale impacts on people, and are further intensified by rapid urbanization, infrastructure expansion, and large numbers of people residing in informal settlements in destitute conditions. This underscores the need to characterize the impacts of extreme precipitation on different stakeholders and help formulate policies and plans to mitigate them. The focus of this paper is on characterizing and analyzing the impacts of extreme precipitation events at the micro level on vulnerable households and small and medium-sized enterprises in three locations in India: Mumbai, Chennai, and Puri district. These areas have faced devastating extreme rainfall events in recent years and offer critical insights into asset the exposure of, and direct and indirect impacts on, urban and rural entities. The flood impact analysis in this paper provides a multidimensional view with quantitative damage estimates and qualitative insights into the devastation and distress caused. It also highlights the heterogeneity of flood impacts and the potential to push the poor into a debt trap and further poverty.
\end{abstract}

Keywords: disaster risk management, extreme events, flooding, household survey, urban poverty

JEL codes: 132, 138, Q54, Q56 


\section{INTRODUCTION}

India's geophysical and climatic conditions make it one of the most disaster-prone countries in the world. Of the different types of natural disaster, hydrological disasters have the largest number of recorded instances and the highest mortality and damage costs. Since the 1990s, floods have accounted for more than half the natural and climate-related disasters in the country, with damage costs running into billions of dollars. The impacts on people of such extreme, large-scale events depends on their vulnerability and exposure. The impacts are further intensified by socioeconomic factors such as population increase, rapid urbanization, infrastructure expansion, and large numbers of people residing in informal settlements in poor and destitute conditions. This underscores the need to characterize the impacts of extreme precipitation on different stakeholders and formulate policies and action plans to mitigate them.

This paper uses field-level and secondary data to characterize and analyze the impacts of extreme precipitation events at the micro level on vulnerable households and small and medium-sized enterprises (SMEs) in three locations-Mumbai, Chennai, and Puri district. Chennai and Mumbai are large megacities with millions of people and critical economic activities. Their coastal locations, land reclamation, and rapid infrastructure expansion in low-lying areas make them highly vulnerable to large-scale flood impacts. Puri district, in contrast, is predominantly rural, and the main livelihoods are agriculture, fishing, and tourism. All three locations have faced devastating extreme rainfall events in recent years and offer rich insights into asset exposure and direct and indirect impacts on urban and rural households and SMEs.

The unique mix of hybrid data, field-level and secondary, is analyzed in this study for assessing flood impacts. Studies conducted by the author in Mumbai, studies carried out by researchers in Chennai, and impact assessment done by government agencies in Puri are extensively used in this paper. This offers a multidimensional view of flood impacts with quantitative estimates and qualitative insights into devastation and distress suffered by different stakeholders. Such insights are normally not captured in routine damage assessments, which focus largely on loss estimates that can be easily quantified. The economic and other impacts of flooding are often not homogenous, and some people and locations tend to be more vulnerable because of socioeconomic and geophysical characteristics. Studies also tend to focus more on household impacts and other vulnerable groups like SMEs remain underinvestigated. This study specially focuses on understanding how and why different stakeholders, such as households and SMEs, are impacted during extreme precipitation and floods.

\section{EXTREME PRECIPITATION: EXPOSURE, VULNERABILITY, AND IMPACTS}

During 1980-2017, more than 5,200 flash flood events were recorded worldwide, with more than 220,000 fatalities and global economic losses of $\$ 1,000$ billion (Munich Re 2018). Asia accounted for $45 \%$ of these events, $74 \%$ of total fatalities, and $57 \%$ of overall losses. India experienced 278 floods during 1980-2017 that affected more than 750 million people and caused about $\$ 58.7$ billion in losses (EM-DAT 2018). Precipitation events in India are generally characterized as extreme when rainfall exceeds 150 millimeters $(\mathrm{mm})$ per day and flooding affects a large area (Goswami et al. 2006; Rajeevan, Bhate, and Jaswal 2008). The scale of the impacts of such events on human and ecological systems depends on changes in climate, vulnerability, and exposure (IPCC 2012). Extreme rainfall and resultant floods cause extensive damage to infrastructure and affect millions of people through loss of life, health impacts, damage to property, and socioeconomic disruption. 
In developing countries such as India, calculations of losses from extreme events are usually lower-bound estimates because impacts, such as the loss of cultural heritage and ecosystem services, are difficult to value and monetize, and impacts on the large informal economy, as well as indirect impacts, are generally hard to estimate (IPCC 2012). Settlement patterns, urbanization, population growth, and changes in socioeconomic conditions also determine exposure and vulnerability to extreme events and the impacts of such events. In future, developing countries such as India, which have large numbers of people living in informal settlements and rising concentrations of people and assets in urban areas, will experience greater direct and indirect losses from extreme precipitation events.

To characterize the impacts of extreme precipitation events, this paper considers three locations: Mumbai in the state of Maharashtra, Chennai in the state of Tamil Nadu, and Puri district in the state of Odisha. Mumbai is the world's fourth-largest megacity with 21.3 million people (United Nations 2016). As India's financial capital and an important sea port, the city is home to large commercial and trading companies, industries, multinational corporations, finance institutions, and defense establishments. Originally a cluster of seven islands, these areas were joined from the 17th century through drainage, reclamation, causeways, and breakwaters to form the present-day landmass (MCGM 2018). The city has a low-lying coastal tract, some of which is barely 1 meter above mean sea level, and its suburbs have four main rivers that drain into the Arabian Sea (MCGM 2018).

Mumbai's average annual rainfall has historically averaged 2,200 $\mathrm{mm}$ with significant variations from 1,299 $\mathrm{mm}$ in 2002 to 3,274 $\mathrm{mm}$ in 2010. The worst extreme precipitation event Mumbai has endured occurred in July 2005, when $944 \mathrm{~mm}$ of rain fell on a single day causing loss of life and millions of dollars in damage. Almost every year since 2006 there have been 2 or 3 days when the 24-hour rainfall total exceeded $200 \mathrm{~mm}$ and could be termed extremely heavy under the revised classification of 24-hour accumulated rainfall.' Thus, Mumbai experiences extreme precipitation events with alarming regularity. Analysis of the probability of such events and their return period based on historical data reveals that in any year, the probability of 24 -hour rainfall exceeding $200 \mathrm{~mm}$ is $50 \%$ for the western suburbs and 33\% for the island city in the Greater Mumbai metropolitan region (MCGM 2006).

Like Mumbai, Chennai is also one of the world's largest megacities. It is ranked 30th and has a population of 10 million (United Nations 2016). The city has been an important trading base since the 17th century and has played the key role as South India's center for art, culture, architecture, and tradition. The city has a diversified economic base of automobile manufacturers, software services, hardware manufacturing, and healthcare and financial services institutions (Government of Tamil Nadu 2018). Its special economic zone caters to apparel and footwear industries and accounts for $50 \%$ of India's leather exports. Chennai receives $45 \%$ of the country's medical tourism. Prominent international finance institutions have back offices and development centers in the city (Government of Tamil Nadu 2018). Located on a flat coastal plain near the equator, annual average rainfall is about $1,300 \mathrm{~mm}$ and is experienced during two seasons - the southwest monsoon (June-September) and the northeast monsoon (October-December). The city is prone to heavy to extreme rainfall during the monsoon seasons and is exposed to cyclones from the Bay of Bengal. It has experienced regular flooding since 1976 and was subject to extreme precipitation in 2015. Heavy rainfall caused major floods in 1976, 1996, and 1998. Between 2005 and 2012, Chennai was also affected by five cyclones that caused heavy losses.

Author's calculations based on data from the Disaster Management Department of the Municipal Corporation of Greater Mumbai. 
Puri district is named after its main town of Puri, which is an ancient town of great cultural significance, and is famous for the Jagannath Temple that attracts thousands of pilgrims and other national and international visitors each year. Unlike Mumbai and Chennai, most (84\%) of Puri's residents live in rural areas. Agriculture is the predominant occupation followed by fishing since the coastal plain also offers rich marine and aquatic resources. During 2009-2018, the government promoted agro-based, textile, chemical, engineering, and rubber-based industries in the district (Government of Odisha 2018). Puri's tropical climate is greatly influenced by proximity to the sea, and has moderate temperatures through the year and annual average rainfall of 1,392 $\mathrm{mm}$ with an average of 62 days of rain during July-September. The state of Odisha has experienced floods every year since 1970, with 6.7 million hectares of crops damaged and more than $\$ 3.14$ billion in losses incurred (UNDRR 2018). Puri district has been one of the areas most affected by recurrent flooding. Since 1990, the district has been affected by floods almost every year. Cyclones in 1999, 2013, and 2014 also brought extreme rainfall and inundation. All villages in the district are vulnerable to the impacts of cyclones, and 760 villages (44\% of the total) are flood prone (Government of Odisha 2018). Vulnerability to floods and cyclones is exacerbated by the large number of small and marginal farmers, landless laborers, and fishing communities in the district.

\section{METHODOLOGY AND DATA}

The focus of this paper is on characterizing impacts of extreme precipitation events and floods on households and businesses in the selected locations. Table 1 outlines the research questions, methods, and data sources used. Disaster risk is a function of hazard, exposure, and vulnerability at a given time in an area or region. To understand flood impacts, it is necessary to understand the nature of the hazard-in this case extreme rainfall-and assess factors that expose people and assets to floods and contribute to their vulnerability. After evaluating the nature of the flood risk in the three locations, this paper focuses on the impacts on households, retail businesses, and SMEs using field-level and secondary data. Economic and other impacts of floods are often not homogenous and some groups tend to be more vulnerable because of the geophysical and socioeconomic characteristics of the settlements in which they live. The paper seeks to understand how different groups of stakeholders are impacted differently and what factors cause these differences.

Table 1: Research Questions, Methodology, and Data Sources

\begin{tabular}{lcc}
\hline Research Questions & Methodology & Data Sources \\
\hline Hazard, Exposure, and Vulnerability & & \\
\hline $\begin{array}{l}\text { What is the nature of the hazard } \\
\text { affecting the selected locations? }\end{array}$ & $\begin{array}{c}\text { Examine trends in extreme } \\
\text { precipitation events for their } \\
\text { frequency, intensity, and duration } \\
\text { Assess past flood events to } \\
\text { understand extent of flooding }\end{array}$ & $\begin{array}{c}\text { Disaster databases EM-DAT and } \\
\text { DesInventar } \\
\text { Rainfall data from the India Meteorological } \\
\text { Department }\end{array}$ \\
$\begin{array}{lll}\text { What makes people and assets } \\
\text { vulnerable to floods in the } \\
\text { selected locations given the } \\
\text { nature of the hazard and } \\
\text { exposure? }\end{array}$ & $\begin{array}{c}\text { Examine socioeconomic } \\
\text { characteristics of flood-prone from local government } \\
\text { areas to identify factors } \\
\text { contributing to vulnerability }\end{array}$ & $\begin{array}{c}\text { Odisha state government reports for Puri } \\
\text { Census data }\end{array}$ \\
\hline
\end{tabular}




\begin{tabular}{|c|c|c|}
\hline Research Questions & Methodology & Data Sources \\
\hline \multicolumn{3}{|l|}{ Characterization of Impacts } \\
\hline \multirow{4}{*}{$\begin{array}{l}\text { What are the impacts of selected } \\
\text { extreme precipitation and flood } \\
\text { events on households and } \\
\text { businesses in each location? }\end{array}$} & \multirow{2}{*}{$\begin{array}{l}\text { Characterize economic and welfare } \\
\text { impacts on households by } \\
\text { analyzing primary and secondary } \\
\text { data }\end{array}$} & $\begin{array}{l}\text { Primary data collected by author in } \\
\text { previous studies of affected households, } \\
\text { retail businesses, and SMEs in Mumbai }\end{array}$ \\
\hline & & Data from studies conducted by CAG \\
\hline & \multirow{2}{*}{$\begin{array}{l}\text { Characterize direct and cascading } \\
\text { impacts on retail businesses and } \\
\text { small and medium-sized } \\
\text { enterprises using primary and } \\
\text { secondary data }\end{array}$} & $\begin{array}{l}\text { (2016) and Mercy Corps and Okapi } \\
\text { (2016) in Chennai }\end{array}$ \\
\hline & & $\begin{array}{l}\text { Data from damage assessment done by } \\
\text { Government of Odisha, ADB, and World } \\
\text { Bank (2013) in Puri district }\end{array}$ \\
\hline \multirow{3}{*}{$\begin{array}{l}\text { How different are impacts of } \\
\text { extreme precipitation compared } \\
\text { to recurrent floods of lesser } \\
\text { magnitude and intensity? }\end{array}$} & \multirow{3}{*}{$\begin{array}{l}\text { Compare the losses from extreme } \\
\text { and other flood events and test if } \\
\text { there are significant differences in } \\
\text { impacts }\end{array}$} & $\begin{array}{l}\text { Primary data collected by author in } \\
\text { previous studies of affected households, } \\
\text { retail businesses and SMEs in Mumbai }\end{array}$ \\
\hline & & $\begin{array}{l}\text { Data from local and state government } \\
\text { reports on Chennai }\end{array}$ \\
\hline & & $\begin{array}{l}\text { Data from damage assessment done by } \\
\text { Government of Odisha, ADB, and World } \\
\text { Bank (2013) in Puri district }\end{array}$ \\
\hline \multirow[t]{2}{*}{$\begin{array}{l}\text { Are the impacts heterogeneous } \\
\text { across different sets of } \\
\text { vulnerable groups and if so, why? }\end{array}$} & $\begin{array}{l}\text { Examine economic and welfare } \\
\text { impacts on poor and nonpoor } \\
\text { households }\end{array}$ & $\begin{array}{l}\text { Primary data collected by author in } \\
\text { previous studies of affected households } \\
\text { in Mumbai }\end{array}$ \\
\hline & $\begin{array}{l}\text { Examine impacts on different types } \\
\text { of business }\end{array}$ & $\begin{array}{l}\text { Data from studies conducted by CAG } \\
\text { (2016) and Mercy Corps and Okapi } \\
\text { (2016) in Chennai }\end{array}$ \\
\hline
\end{tabular}

Source: Author.

As more extreme rainfall events occur in different parts of India, a better understanding of exposure, vulnerability, and impacts at the micro level will help improve adaptation responses and reduce future risk.

\section{ASSESSING IMPACTS}

To evaluate the impacts of extreme precipitation on exposed and vulnerable groups, some of the most extreme events in recent history in terms of intensity and magnitude were selected in each location. The impacts of floods on people and assets in these areas were identified, quantified where feasible, and compared using primary and secondary data.

Mumbai experienced the most extreme precipitation in its history on 26 July 2005 when a cloudburst resulted in record rainfall of $944 \mathrm{~mm}$ over the city's suburbs. The city recorded $43 \%$ of its annual average rainfall amount in a single day. The rainfall intensity was 5 times greater than that the old storm water drainage system was designed to accommodate and 2.5 times more than the current system is designed to cope with (MCGM 2006). The city administration had no experience of dealing with an event of this magnitude. Combined with a high tide, the unprecedented rainfall brought Mumbai to a standstill, stranding 2 million people on the roads and 2.5 million in partly or fully submerged houses (MCGM 2006). Basic services, such as electricity, water supply, transport, and communication, were shut down, and it took 1-4 weeks for them to start functioning smoothly again.

Estimated losses ranged from $\$ 1.1$ billion to $\$ 5$ billion depending on the evaluation methodology used. However, these damage assessment exercises did not reflect the extent of vulnerability and 
impacts on households, particularly the poor residing in informal settlements, and on the small retail businesses in the informal sector (Patankar and Patwardhan 2015). To focus on these vulnerable segments, primary surveys were carried out among affected households and retail businesses (Patankar et al. 2012, Patankar 2015). Estimates of losses were also obtained from SMEs as part of another study (Schaer and Patankar 2018). This paper uses some of these studies' findings to characterize the impacts of the flood on vulnerable segments of the population.

A similar precipitation event occurred in Chennai during the northeast monsoon from November to December 2015 when extremely heavy rains fell over the city due to the formation of a depression over the Bay of Bengal and a strong El Niño event (ISRO 2015). A period of heavy, incessant rainfall began when $167 \mathrm{~mm}$ fell on 9 November 2015. On 1 December, the city recorded $290 \mathrm{~mm}$ of rainfall, and the next day Chennai experienced $320 \mathrm{~mm}$ - the highest rainfall in a single day (GCC 2017). This deluge came after $1,200 \mathrm{~mm}$ of rainfall in November-300\% more than the usual average for the month (ISRO 2015). The ensuing flooding brought Chennai to a standstill for many days. Residential areas along water bodies (the Cooum and Adyar rivers and micro drainage canals) and those encroaching over them remained submerged for more than 10 days. The international airport was inundated and had to be shut down for a week. Industries and the commercial sector reported heavy losses due to direct damages and closure for several days. To assess the extent of vulnerability and impacts on households, a primary survey was carried out in some of the most affected areas around Chennai (CAG 2016). A similar survey was carried out among SMEs, which form an important part of the local and state economy (Mercy Corps and Okapi 2016). This paper uses findings from both studies to understand flood impacts on households and SMEs.

For Puri district, the paper considers the extreme rainfall caused by Cyclone Phailin. On 12 October 2013, Cyclone Phailin, a very severe cyclonic storm, passed over the state of Odisha and the northern coast of the state of Andhra Pradesh. It made landfall in Ganjam District, Odisha, bringing sustained maximum wind speeds of 200-220 kilometers per hour (NIDM 2014). The cyclone brought very heavy to extremely heavy rainfall to Odisha and storm surges of 3.5 meters, inundating extensive low-lying areas in the districts of Puri, Ganjam, and Khordha, and Chilika Lake (NIDM 2014). Although the mass evacuation executed during the cyclone is considered a success story of disaster management for limiting loss of life and the extent of damage compared with the super storm of 1999 (Government of Odisha, ADB, and World Bank 2013), people suffered significant impacts during the cyclone. This paper uses the damage assessment report (Government of Odisha, ADB, and World Bank 2013) and damage estimates for Puri district (Government of Odisha 2018) to analyze the flood's impacts on households and small businesses.

\section{A. Household Impacts}

Extreme precipitation events lead to losses that are a combination of (i) physical, financial, and human capital damage costs; and (ii) reductions in the economic activities of consumption, production, investment, and employment (World Bank 2004). Most of the literature on natural hazards and their impact focuses on the first types of losses, where short-term and immediate damages to property and physical assets can be estimated using insurance values. When insurance penetration is very high, as in the case of developed countries, damage is assessed using insured exposure analysis (Hallegatte et al. 2011). However, in developing countries such as India, nonlife (general) insurance penetration is quite low at $0.93 \%$ and insurance density is $\$ 13.2$ (compared with a global average of $\$ 285.3$ ) (Government of India 2018). Using insurance estimates to quantify the impacts of extreme events may therefore not reflect the true losses. 
Empirical studies assessing flood-related damages focus mostly on capturing losses at the macro or meso levels where affected assets are aggregated across the affected area using land use and hazard -exposure maps and census data (Merz et al. 2010). These studies consider only direct and tangible damages because indirect damages, such as the effect on the provision of goods and services, water supply, electricity, and transport, are difficult to estimate because of a lack of data and measurable variables (World Bank 2004). However, a few studies have tried to assess flood impacts at the micro level using household or community surveys. They include a study in Limpopo Province, South Africa, using structured household interviews (Khandlhela and May 2006); a primary survey of affected floodplain residents in Bangladesh (Brouwer et al. 2007); a multi-country study to assess climate change impacts on households (Warner and van der Geest 2013); and a study in Nepal that constructed a household vulnerability index using primary data (Piya, Maharjan, and Joshi 2012).

This section focuses on micro-level analysis of the impacts of extreme precipitation and resultant floods across the three locations as assessed and characterized in different studies using primary surveys and secondary data from field reports of government and research organizations. Single households or businesses are the units of analysis, and the focus is on estimating direct and tangible losses. The losses are disaggregated into monetary damage to property, physical assets, appliances, equipment, and products, as well as loss of income, investment, and other impacts. Indirect impacts, such as disruption of basic services, are difficult to measure, but their overall effect on households and businesses has been captured qualitatively through the surveys.

\section{Mumbai}

To estimate the impacts of extreme precipitation in July 2005 on households in Mumbai, the author carried out a detailed survey in the worst affected wards: F North, F South, K East, H East, L Ward, and P North (Patankar et al. 2012). This study uses the primary database from this survey to estimate and characterize the flood's impacts. The selected wards are acutely vulnerable to flooding because of their location in reclaimed areas, low-lying areas, or on the river flood plain. The wards contain key infrastructure, such as the international airport, highways, interconnecting subways, and suburban railway stations, and a large percentage of their residents live in informal settlements (Table 2 ).

Table 2: Profile of Surveyed Wards in Mumbai

\begin{tabular}{lccccccc}
\hline Ward & $\begin{array}{c}\text { Area } \\
\left(\mathrm{km}^{2}\right)\end{array}$ & $\begin{array}{c}\text { Residential } \\
\text { Area } \\
\left(\mathrm{km}^{2}\right)\end{array}$ & $\begin{array}{c}\text { Residential } \\
\text { Density }\end{array}$ & $\begin{array}{c}\text { Total } \\
\mathrm{HHs}\end{array}$ & $\begin{array}{c}\text { Slum } \\
\mathrm{HHs}\end{array}$ & $\begin{array}{c}\text { S of } \\
\text { HHs }\end{array}$ & $\begin{array}{c}\text { Number of } \\
\text { HHs } \\
\text { Surveyed }\end{array}$ \\
\hline F North & 12.01 & 4.03 & 131,411 & 132,259 & 61,680 & 46.6 & 177 \\
F South & 9.65 & 2.34 & 154,380 & 90,243 & 19,040 & 21.1 & 103 \\
H East & 12.89 & 2.83 & 199,280 & 140,861 & 48,201 & 34.2 & 176 \\
K East & 24.00 & 6.85 & 120,200 & 205,971 & 80,760 & 39.2 & 241 \\
L Ward & 15.56 & 5.45 & 165,573 & 225,556 & 98,080 & 43.5 & 231 \\
P North & 46.72 & 10.27 & 91,645 & 235,342 & 100,900 & 42.9 & 240 \\
\hline
\end{tabular}

$\mathrm{GIS}=$ Geographic Information System, HH = household, $\mathrm{km}^{2}$ = square kilometer, MCGM = Municipal Corporation of Greater Mumbai.

a Households surveyed as part of the study presented in Patankar et al. 2012.

Source: Calculations based on GIS-based exposure maps developed by author for affected wards using existing land use maps of the MCGM and superimposing flood maps of the Disaster Management Unit of MCGM. 
To understand the nature and magnitude of the impacts of extreme precipitation in July 2005, the study randomly selected 1,168 families from the chosen wards to administer primary surveys. These households were classified into socioeconomic categories to contextualize the total damage they reported (Figure 1). According to the urban poverty line estimated using the Tendulkar method, the approximate per capita income of the urban poor in Maharashtra is 1,000 Indian rupees (₹) (Government of India 2013). The 2011 census estimated that families in slum settlements have five members, so families with a monthly income of less than ₹5,000 are classified here as below poverty line (BPL) households. Similarly, based on the income distribution analyzed by Annez et al. (2010), other families are classified as poor or belonging to lower-income, medium-income, or highermedium-income groups. This classification of surveyed households is used throughout the flood impact analysis presented here.

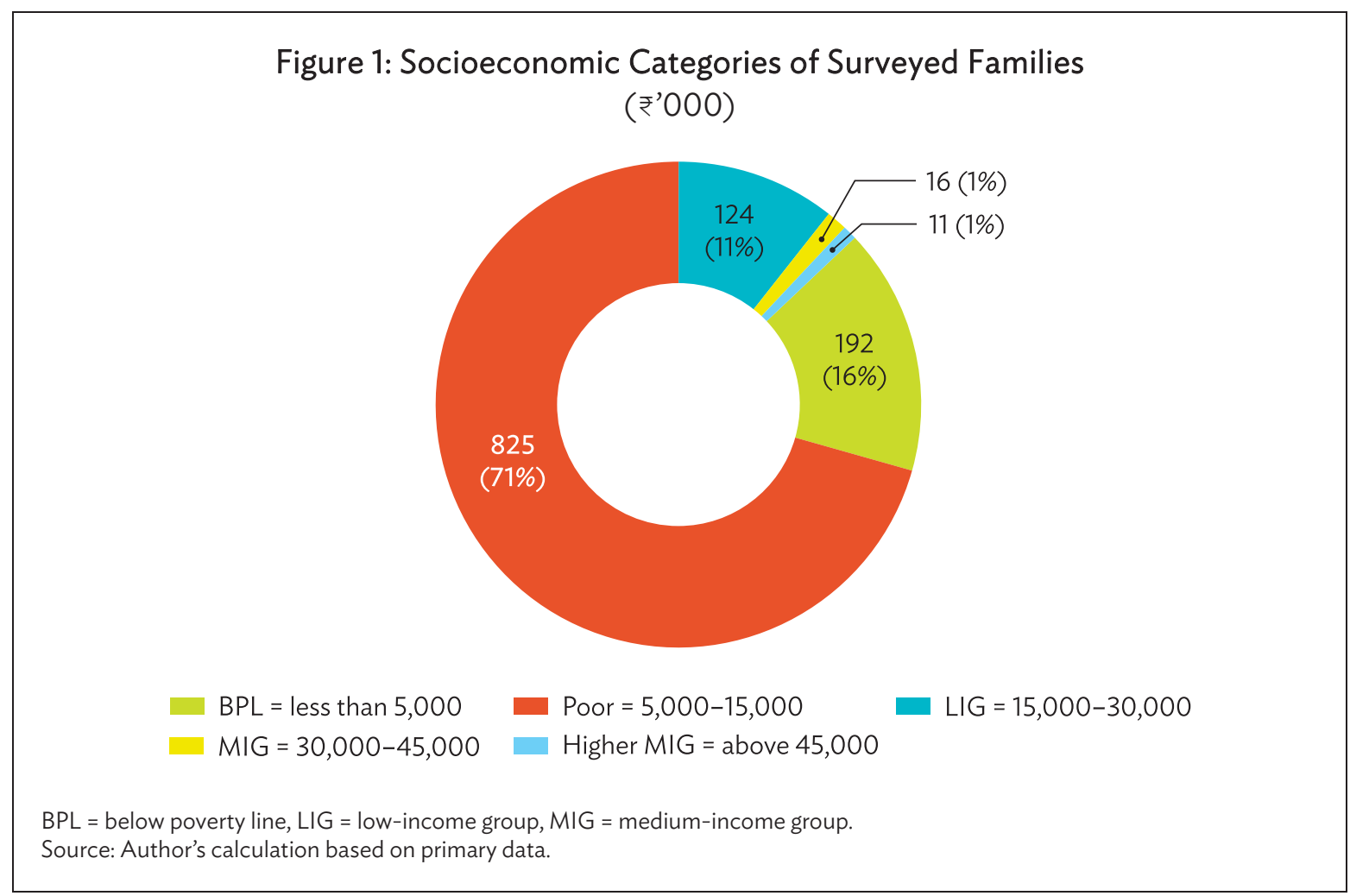

A family's house is usually its most important asset and investment. Its location, type of construction, material used for construction, other amenities, and general surroundings determine the family's vulnerability to natural hazards such as flooding. Most surveyed households were poor and lived in poorly constructed, dilapidated houses in poorer neighborhoods. The surveyed households were classified into the standard dwelling types, kutcha, semi-pucca, and pucca houses, that are mainly found in slums and are single- and multistory building types found in apartment blocks. ${ }^{2}$ More than $90 \%$ of the surveyed families lived on the ground floor and suffered direct impacts when their houses were flooded with rainwater, sewage, and garbage.

2 According to the NSSO (2010) classification, kutcha houses have walls and roofs made of materials such as unburnt bricks, bamboo, mud, and grass. Pucca houses have walls and roofs made of materials such as cement, concrete, bricks, metal sheets, and polyvinyl chloride. Semi-pucca structures are a combination of kutcha and pucca structures. 
Most (87\%) of these households owned the houses they lived in and had invested their earnings and life savings to build their asset base. During the extreme floods of 2005, the average flood depth was 5 feet, and in some areas, it reached a depth of 8 feet. Houses remained flooded for an average of 3 days and in some cases, up to a week. These families suffered heavy damage to the structure of their houses and their assets, but only $6.8 \%$ reported having any form of insurance cover (life, medical, or general) and only 3.6\% raised claims for insurance to cover their losses. Thus, almost all surveyed families used their own funds to cover their losses.

Households across all socioeconomic categories reported extensive damage on account of extreme rainfall on 26 July 2005 and the unprecedented flooding. Table 3 lists the average estimated repair or replacement cost of damage to different assets and equipment. Affected households reported the following categories of damage: house structure (floor, walls, roof); household appliances (television set, refrigerator, washing machine, stove, computers); household assets (furniture, utensils); and vehicles (bicycles, motorbikes, three wheelers, cars).

Table 3: Estimated Repair or Replacement Cost of Damage

\begin{tabular}{lcccccc}
\hline $\begin{array}{l}\text { Socioeconomic } \\
\text { Category }\end{array}$ & $\begin{array}{c}\text { House } \\
\text { Repair } \\
(₹)\end{array}$ & $\begin{array}{c}\mathrm{HH} \\
\text { Appliances } \\
(₹)\end{array}$ & $\begin{array}{c}\mathrm{HH} \text { Assets } \\
(₹)\end{array}$ & $\begin{array}{c}\text { Vehicles } \\
(₹)\end{array}$ & $\begin{array}{c}\text { Total } \\
\text { Damage Cost } \\
(₹)\end{array}$ & $\begin{array}{c}\text { Share of Average } \\
\text { Monthly Income } \\
(\%)\end{array}$ \\
\hline Below poverty line & 15,000 & 11,000 & 6,700 & 6,500 & 37,000 & 1,480 \\
Poor & 22,000 & 13,000 & 7,000 & 9,000 & 48,000 & 480 \\
Low-income group & 30,000 & 14,000 & 10,000 & 10,000 & 57,000 & 253 \\
$\begin{array}{l}\text { Medium-income } \\
\text { group }\end{array}$ & 45,000 & 17,000 & 13,000 & 2,500 & 69,000 & 184 \\
$\begin{array}{l}\text { Higher-medium- } \\
\text { income group }\end{array}$ & 40,000 & 19,000 & 8,500 & 5,000 & 69,000 & 115 \\
\hline
\end{tabular}

$\mathrm{HH}=$ household.

Source: Author's calculation based on primary data.

The largest amount was spent on house repairs, followed by repairs or replacements of household appliances. Families that could afford to own more household appliances and assets, such as families categorized in the low-income, medium-income, or higher-medium-income groups, reported higher associated damage costs. They experienced extensive damage to television sets, refrigerators, washing machines, furniture items, and motorbikes, which are expensive to repair or replace. The overall damage costs increased in ascending order of income category in the survey. However, the scale of the damage costs does not paint the true picture of hardships suffered by poorer families. Considering the mid value of each income category, the damage cost of the extreme precipitation of 2005 amounted to 1,480\% of the average monthly income of BPL families and $480 \%$ of the monthly income of poor families. In absolute terms, this means BPL families lost the equivalent of more than 12 months' income due to damage to their meager assets. This compares with 5 months' income for poor households and 1-2 months' income for other groups.

This important finding highlights the extent to which the asset base of the poorest families is threatened by an extreme event. Assets in which families invest their lifetime earnings and savings, such as their house, appliances, and furniture, are affected the most by floods. Lacking adequate compensation, social protection, or insurance coverage, these families must bear the costs themselves using savings or by borrowing. Thus, extreme precipitation events have the potential to push poor 
families into a debt trap and even below the poverty line if there is no support mechanism to help them overcome their losses.

Besides the direct impacts on their assets, families reported several indirect impacts (Figure 2). Almost all families experienced power supply disruption. Most also had to cope with garbage left behind by the receding floodwater; fuel, food, and drinking water shortages; and transport disruption. People had to pay higher prices for essential items. Although the monetary cost of these indirect impacts cannot easily be measured in the absence of reliable data and measurable variables, it is clear that there would have been serious disruption of economic activity and substantial economic losses for households and businesses.

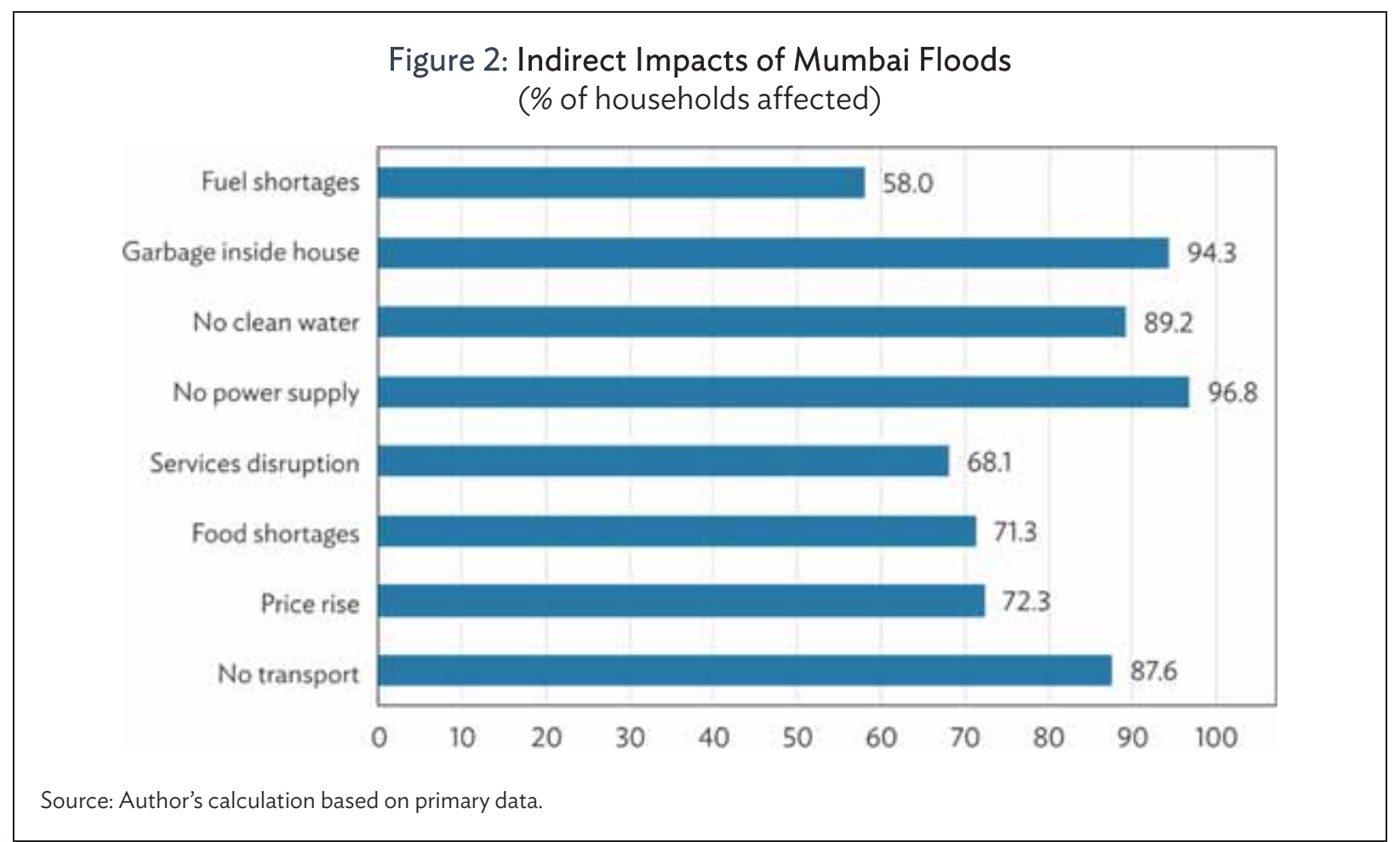

One of the most critical impacts of floods is the incidence of vector-borne and waterborne diseases and respiratory ailments. Table 4 shows the health impact in the immediate aftermath of extreme floods as reported by government hospitals. The impact would be considerably higher if admissions to private hospitals were included. 
Table 4: Number of Admissions at Government Hospitals

\begin{tabular}{lccc}
\hline Disease & $\begin{array}{c}\text { Admissions in } \\
\text { Last 24 Hours }\end{array}$ & $\begin{array}{c}\text { Total Admissions } \\
\text { Since 29 July 2005 }\end{array}$ & Deaths \\
\hline Gastroenteritis & 154 & 1,318 & 1 \\
Hepatitis & 27 & 194 & 0 \\
Typhoid & 5 & 53 & 0 \\
Malaria & 62 & 406 & 2 \\
Dengue & 5 & 49 & 0 \\
Leptospirosis & 56 & 197 & 10 \\
Fever (unknown cause) & 597 & 1,044 & 45 \\
Total & 906 & 3,261 & 58 \\
\hline
\end{tabular}

Note: Data are as of 12 August 2005.

Source: Patankar et al. (2012).

As households across the affected parts of Mumbai suffered substantial losses during unprecedented floods, the state government offered monetary compensation-known as gratuitous relief assistance-as predetermined by the Government of Maharashtra's standing orders of 1983. Affected families were offered ₹5,000 to assist with their immediate requirements such as food and clothing. However, the amount of relief given was unrelated to the actual losses reported by the families because the government did not carry out a postdisaster assessment to capture losses suffered by families who had no social protection or insurance coverage to shield them. Government compensation only covered $13.5 \%$ losses of BPL families and $10.4 \%$ of those suffered by poor households (Figure 3 ). And while the absolute amount of compensation might appear to be slightly pro poor as it offers more for the losses of poor households than better-off households, on a per capita basis, the compensation for a BPL family was only ₹ 1,000 (assuming an average of five members per family) compared with $₹ 1,250$ for others (with four members per family) (Patankar 2015). Thus, even this meager compensation favored better-off households rather than their poorer counterparts (Patankar 2015).

Figure 3: Compensation as a Percentage of Total Damage Cost

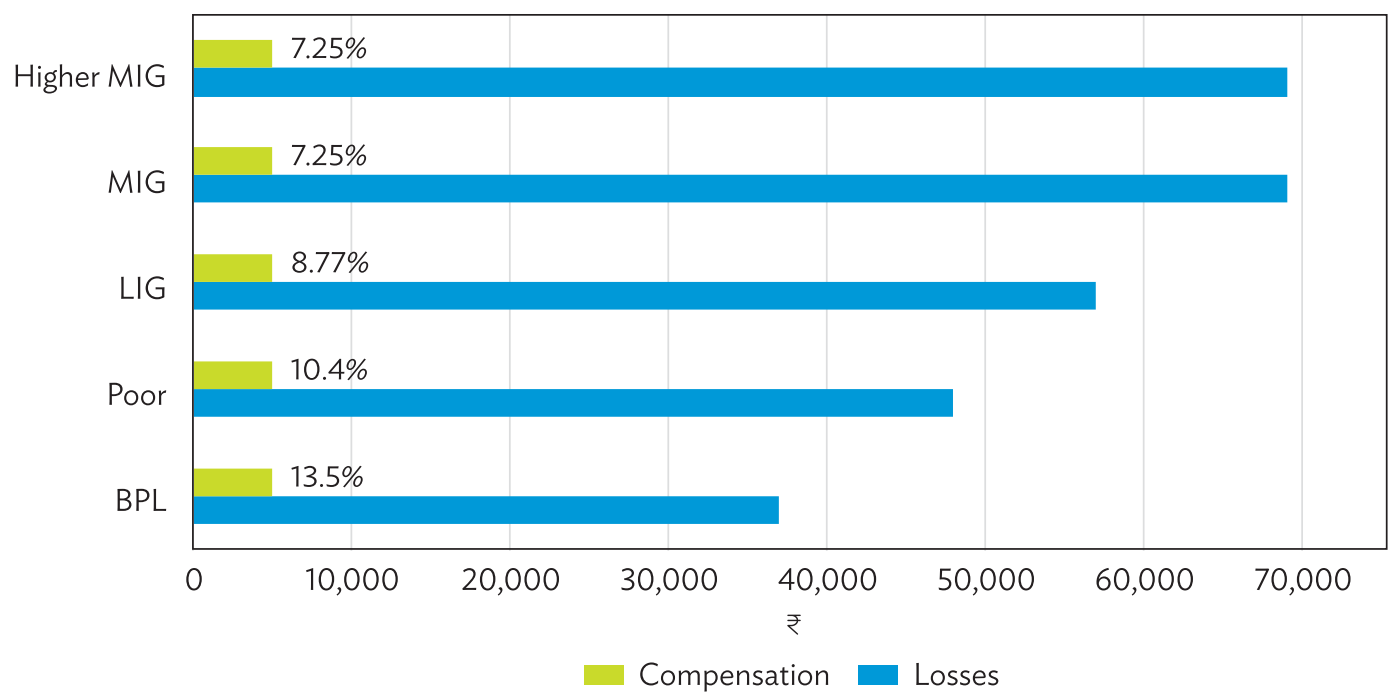

$\mathrm{BPL}=$ below poverty line, $\mathrm{LIG}=$ low-income group, $\mathrm{MIG}=$ medium-income group.

Source: Author's calculation based on primary data. 


\section{Chennai}

Chennai suffered from incessant rainfall during November 2015 and extreme single-day precipitation on 2 December 2015, which led to large-scale inundation across the city. Community-based organizations and concerned citizens involved in relief work carried out a damage assessment of households in some of the city's worst affected areas (CAG 2016). This section uses the findings of the sample survey conducted during that assessment exercise to understand the extent of losses suffered by affected families, the loss of jobs or workdays, and the families' experiences during relief operations after the floods had ravaged their homes and possessions.

Some of the worst affected areas were Mudichur, West Tambaram, Manapakkam, Saidapet, Kotturpuram, and Zafferkhanpet (GCC 2017) As the water-holding tanks on the outskirts of Chennai district overflowed after excessive rainfall, flooding occurred in areas near the main Adyar and Cooum rivers. The carrying capacity of Cooum and Buckingham canals exceeded their design capacity. These major canals and 31 minor ones overflowed and inundated nearby areas. The Greater Chennai Corporation recorded flooding in 859 locations across the city (GCC 2017).

The damage assessment study included a sample survey of 610 households in some of these worst affected areas. The location characteristics of these areas are very important because they play a critical role in vulnerability to floods. Table 5 provides details of the surveyed areas and their household profiles.

Table 5: Profile of Household in Surveyed Areas of Chennai

\begin{tabular}{|c|c|c|c|c|}
\hline Survey Area & $\begin{array}{l}\text { Number of } \\
\text { Households }\end{array}$ & $\begin{array}{l}\text { Location } \\
\text { Characteristics }\end{array}$ & Household Profile & House Type \\
\hline Saidapet & 200 & Adyar River floodplain & Low-income families & Constructed single-story houses \\
\hline Ponneri & 77 & $\begin{array}{l}\text { Fringe area on } \\
\text { Chennai outskirts }\end{array}$ & $\begin{array}{l}\text { Working class and } \\
\text { lower-middle class }\end{array}$ & Constructed single-story houses \\
\hline Perumbakkam & 52 & $\begin{array}{l}\text { Resettled } \\
\text { communities }\end{array}$ & $\begin{array}{l}\text { Very poor and low- } \\
\text { income families }\end{array}$ & $\begin{array}{l}\text { Kutcha houses in informal } \\
\text { settlements, constructed } \\
\text { multistory tenements of } \\
\text { housing board }\end{array}$ \\
\hline Mudichur, Tambaram & 42 & New residential areas & Middle class & $\begin{array}{l}\text { Constructed single- or } \\
\text { multistory houses }\end{array}$ \\
\hline Semmencheri & 50 & $\begin{array}{l}\text { Resettled } \\
\text { communities }\end{array}$ & Low-income families & Constructed single-story houses \\
\hline $\begin{array}{l}\text { Kotturpuram, Raja } \\
\text { Annamalaipuram }\end{array}$ & 54 & Adyar River floodplain & Low-income families & $\begin{array}{l}\text { Constructed single- or multistory } \\
\text { houses }\end{array}$ \\
\hline Ekkatuthangal & 11 & Adyar River floodplain & Low-income families & $\begin{array}{l}\text { Constructed single- or multistory } \\
\text { houses }\end{array}$ \\
\hline $\begin{array}{l}\text { Puttamma Nagar, } \\
\text { OMR Taluk }\end{array}$ & 46 & $\begin{array}{l}\text { Interstate migrant } \\
\text { population }\end{array}$ & Low-income families & $\begin{array}{l}\text { Pucca houses in informal } \\
\text { settlements }\end{array}$ \\
\hline $\begin{array}{l}\text { Semencherry } \\
\text { Thoppu, OMR }\end{array}$ & 10 & $\begin{array}{l}\text { Interstate migrant } \\
\text { population }\end{array}$ & Very poor families & $\begin{array}{l}\text { Kutcha houses in informal } \\
\text { settlements }\end{array}$ \\
\hline Jaffarkhanpet & 20 & Adyar River floodplain & Low-income families & $\begin{array}{l}\text { Constructed single- or multistory } \\
\text { houses }\end{array}$ \\
\hline $\begin{array}{l}\text { Kodungaiyur, MGR } \\
\text { Nagar }\end{array}$ & 48 & $\begin{array}{l}\text { North Chennai } \\
\text { neighborhood }\end{array}$ & Low-income families & Constructed houses \\
\hline
\end{tabular}

OMR = Old Mahabalipuram Road.

Source: Author's compilation based on CAG (2016). 
The damage assessment survey captured the types of damage suffered by flood-affected households, although monetary estimates for individual damage categories are not available. Because the survey was carried out by volunteers participating in the postdisaster relief work, the interviewers were able to see how houses had been damaged and how the families had suffered as a result of the floods. Based on the reported losses, the volunteers recorded five types of damage: (i) house structure (damage to floor, roof, walls, and access roads); (ii) household assets (provisions, furniture, clothes, books, and important documents); (iii) appliances (refrigerator, washing machine, fans, and lights); (iv) vehicles (bicycles and motorbikes); and (v) work tools (sewing machines, carpentry tools, equipment, and inventory).

The interviewers gained important insights into flood-related damage. Average total losses reported by surveyed families ranged from ₹7,500 to ₹125,000. No breakdown of the damage costs is available. Poor migrant families in the Old Mahabalipuram Road settlement near Semmencheri reported the lowest average losses because the rains in November had prevented the migrant workers from finding gainful work and therefore they had no possessions to lose in the December floods. Their kutcha houses were, however, destroyed by waterlogging. Families who lost occupational tools in addition to their household assets reported higher average losses of ₹100,000-₹125,000.

Almost all families in the selected areas reported significant damage to the structure of their homes. In Ponneri, Old Mahabalipuram Road settlement near Semmencheri, and Zaffarkhanpet, houses were washed away or partly destroyed and people had to move to shelters. Houses in Kotturpuram, Ekkatuthangal, and Kodungaiyur suffered extensive structural damage. Families in Semmencheri also reported robberies as houses that had filled with water and garbage had to be abandoned.

Many families lost important identification, bank, or insurance documents and certificates along with other household assets such as clothes, provisions, and furniture. This was a significant loss with serious short- to medium-term implications for affected families. Identification documents were required to claim relief for damage or establish ownership of houses and other assets. It would also have been difficult to restore bank and insurance documents or education certificates.

Many households lost work tools, such as sewing machines, carpentry tools, and printing machines, and small shops lost inventory. The consequent short-term loss of livelihood until the tools could be repaired or replaced put an additional financial burden on low-income households with limited means and no social or insurance protection to cover such losses.

Most families reported loss of 15-45 workdays with an average loss of wages of ₹250-₹500 per day. In addition, some people lost their job because they could not report to work for more than 2 weeks. This includes families working as domestic helpers in wealthier households in the city. Many people also had to relocate, either to relatives' houses or to their native town or village, and hence, lost workdays or jobs.

Overall, flood-affected households experienced damage to assets in which their life savings were invested (houses) or on which their livelihood depended (work tools). This underlines how extreme events threaten the critical asset base of poor families. The lack of a protective net offered by social security or insurance to help poor families rebuild their lives pushes them into a debt trap and makes them poorer. 
Besides the direct impacts in terms of damage to household assets and work tools, households described several indirect impacts to the interviewers. People suffered from power cuts, food and water shortages, higher prices, and lack of transport. Many neighborhoods remained inundated for 2-3 weeks, hampering families' efforts to recover from losses and rebuild their lives. People had to leave houses filled with water and garbage and move to shelters run by the government or private groups or to friends' or relatives' houses.

Most families received no flood warning. In some cases, by the time warning was issued, floodwaters had already risen and people could not move to higher ground in time and protect important assets and documents. Those who could not move to a safer place waited on top floors or roofs for rescue and relief material. Airdropped relief packages often became scattered and people could not access and use them. In some areas, relief material and rescue boats reached houses located along the roads, but those living in the interior parts of affected neighborhoods remained without assistance.

Migrant families were denied shelter and relief by government officials because they did not have voter or ration cards with which to establish their identity. These poor families had to look for alternative short-term rental accommodation. They were also denied government compensation of $₹ 5,000$. Women who lost their jobs and did not have male family members to support them also suffered from the fear of being pushed into a long-term debt trap. Families that had been resettled from previously vulnerable areas once again suffered from floods, raising serious questions about the quality of resettlement and rehabilitation.

Insights from the damage assessment survey of affected households thus raised important questions regarding (i) the long-term economic impacts of extreme events on poor families, (ii) the need for a protective social safety net to prevent their downward spiral into a debt trap and poverty, (iii) the missing human angle during the rescue and relief operations under disaster management and while providing relief and compensation to the affected people.

\section{Puri District}

Cyclone Phailin made landfall at Ganjam in the state of Odisha on 12 October 2013, where it caused extremely heavy rainfall and large-scale inundation. In response to a request from the Government of India's Department of Home Affairs, the Government of Odisha, the Asian Development Bank, and the World Bank jointly prepared a rapid damage and needs assessment report of this event (Government of Odisha, ADB, and World Bank 2013). The team visited the worst affected districts of Ganjam, Khordha, and Puri and assessed the damage to households and rural and urban infrastructure, and the cyclone's impacts on agriculture, fisheries, and handicrafts. Sector teams used customized templates to collect and aggregate data. This section analyzes the aggregated database generated by this damage assessment exercise. It also includes information on compensation for different types of damage sourced from the district disaster management plan documents to estimate the monetary burden on households (Government of Odisha 2018). No primary surveys were carried out after Cyclone Phailin to record damage suffered by individual households. Hence, there are no databases to evaluate how people dependent on agriculture and other rural occupations were affected.

The cyclone and floods affected 1.75 million people (350,000 households) in Puri, but the death toll of Cyclone Phailin was far lower than that of the 1999 super cyclone (Table 6). The Government of Odisha and the coastal communities responded to the cyclone warning in an effective 
and coordinated manner a day before it was expected to make landfall. More than 1.3 million people evacuated from coastal areas and moved to shelters. The armed forces, central and state government disaster management authorities, the local administration, political and social organizations, and residents worked together in the rescue operation (NIDM 2014). The effective early warning and dissemination of the warning, prompt disaster planning, and preparedness of the administration helped ensure minimum fatalities during one of the most severe storms and what is now considered a success story of disaster management and adaptation (NIDM 2014, Walch 2018).

Table 6: Households Affected by Cyclone Phailin

\begin{tabular}{lrr}
\hline & Total & Puri District \\
\hline Deaths & 44 & 4 \\
Impacted population (million) & 13.0 & 1.75 \\
Impacted households & $2,600,000$ & 350,000 \\
Rural ${ }^{a}$ & $2,158,000$ & 297,500 \\
Urban & 442,000 & 52,500 \\
Fisher households & 44,806 & 58,268 \\
Artisan households & 1,564 & 722 \\
\hline a $\quad$ Rural households are assumed to make up 83\% of households in Odisha state and 85\% of households \\
in Puri, as stated in the 2011 census.
\end{tabular}

However, rural households suffered severe damage. Many houses in Puri district were partly or completely damaged. The cost of reconstruction was estimated at ₹1,471.18 million ( $\$ 21$ million), including land acquisition for relocation, repair of damaged houses, and the provision of basic services such as electricity and water supply. ${ }^{3}$ Partly damaged kutcha houses were offered ₹3,200 and pucca houses ₹5,200 as compensation under the State Disaster Response Fund and the National Disaster Response Fund (Government of Odisha 2018). Based on these figures, the total compensation is estimated at ₹228.04 million ( $\$ 3.26$ million), or $15.5 \%$ of total reconstruction costs. Households bore the remaining costs of reconstructing their damaged or destroyed houses - an amount equivalent to $1,965 \%$ of their monthly income.

Odisha is a predominantly rural state where most families depend on agriculture and allied activities for their livelihood. Table 7 estimates the impact of the cyclone and flooding on agriculture. The estimated cost of all agricultural land affected and rainfed, irrigated, or perennial farmlands with $50 \%$ or more crop losses is ₹2,345 million for Puri district. The potential compensation for crop losses of more than $50 \%$ is ₹ 12,200 per hectare (Government of Odisha 2018). Thus, families that lost more than half of their crops would receive compensation from disaster response funds amounting to $34.31 \%$ of losses incurred and would have to bear the remaining costs from their own resources. Similar estimates are developed for households engaged in horticulture and livestock rearing. Overall, losses borne by households dependent on agriculture and allied activities are estimated at ₹1,654.73 million ( $\$ 23.64$ million), or $111.78 \%$ of households' monthly income.

$3 \$ 1=₹ 69.58$ (as of 30 April 2019). 
Table 7: Impact of Cyclone Phailin on Agriculture

\begin{tabular}{lrr}
\hline Item & Total & Puri District \\
\hline Agriculture & & \\
\hline Agricultural land affected (hectares) & $1,292,967$ & 141,271 \\
Estimated loss to crop (₹ million) & $17,785.53$ & $2,345.06$ \\
Potential compensation to farmers (₹ million) & $6,686.73$ & 804.55 \\
Compensation as a percentage of total loss (\%) & 37.60 & 34.31 \\
\hline Horticulture & & 136 \\
\hline Estimated loss of horticulture (₹ million) & $1,553.30$ & 30.89 \\
\hline Potential compensation as input subsidy (₹ million) & & 22.72 \\
\hline Compensation as a percentage of total loss (\%) & & 16.24 \\
\hline Livestock & 274.19 & 7.12 \\
\hline Estimated loss of livestock (₹ million) & 39.20 & 43.84 \\
\hline Potential compensation for dead livestock (₹ million) & 14.30 & \\
Compensation as a percentage of total loss (\%) & & $2,497.30$ \\
\hline Total & $19,613.02$ & 842.57 \\
\hline Total loss of rural households (₹ million) & $5,883.91$ & 33.74 \\
\hline Total potential compensationa (₹ million) & 30.00 & $1,654.73$ \\
Compensation as a percentage of total loss (\%) & $13,729.11$ & $5,562.13$ \\
\hline Loss to be borne by households (₹ million) & $6,361.96$ & 111.78 \\
\hline Loss per household (₹ million) & 127.85 & \\
Loss as a percentage of monthly income (\%) & & \\
\hline
\end{tabular}

${ }^{a}$ It is assumed that the government will offer an average of $30 \%$ of total loss as compensation.

Source: Author's calculations based on data in Government of Odisha, ADB, and World Bank (2013) and Government of Odisha (2018).

For families dependent on fishing, the potential compensation offered for losses incurred was a meager $2.4 \%$ of the total loss (Table 8 ).

Table 8: Impact Cyclone Phailin on Fisheries

\begin{tabular}{lrr}
\hline Item & \multicolumn{1}{c}{ Total } & Puri District \\
\hline Fishermen affected (number) & 44,806 & 17,336 \\
Total losses (₹ million) & $6,047.00$ & $2,139.00$ \\
Potential compensation for boats (₹ million) & 38.83 & 27.35 \\
Potential compensation for nets (₹ million) & 59.93 & 24.67 \\
Total compensation (₹ million) & 98.76 & 52.02 \\
Loss to be borne by fishing households (₹ million) & $5,948.24$ & $2,086.98$ \\
Compensation as percentage of total loss (\%) & 1.63 & 2.43 \\
\hline
\end{tabular}

Source: Author's calculations based on data in Government of Odisha, ADB, and World Bank (2013) and Government of Odisha (2018). 
Based on reports and estimates of losses and costs of reconstruction, Table 9 compiles the total estimated reconstruction cost for Odisha state and Puri district. The cost includes reconstruction of damaged houses; loss of agriculture and fishing households; and damage to nonresidential buildings such as schools and health facilities, roads, water supply, and urban infrastructure. Given the norms for compensation, $56 \%$ of reconstruction costs would be borne by households across the affected areas in the state. For Puri district, compensation would cover 33\% of the damage, with the remaining $67 \%$ to be borne by households using their own resources. Given the annual per capita income of $\$ 881$ in the district, households would have to spend more than 2 months' income to compensate for the losses from torrential rains and flooding.

Table 9: Estimated Reconstruction Cost for Damage Caused by Cyclone Phailin

\begin{tabular}{|c|c|c|c|c|c|c|}
\hline Reconstruction Cost & Total & Government & Households & Puri District & Government & Households \\
\hline $\begin{array}{l}\text { Housing, basic services, } \\
\text { and land acquisition } \\
\text { (₹ million) }\end{array}$ & $29,601.19$ & $4,375.26$ & $25,225.93$ & $1,471.18$ & 228.04 & $1,243.14$ \\
\hline $\begin{array}{l}\text { Nonresidential buildings } \\
\text { (₹ million) }\end{array}$ & $6,444.15$ & $6,444.15$ & & 204.33 & 204.33 & \\
\hline $\begin{array}{l}\text { Rural roads } \\
\text { (₹ million) }\end{array}$ & $7,007.87$ & $7,007.87$ & & 475.00 & 475.00 & \\
\hline $\begin{array}{l}\text { Urban infrastructure } \\
\text { (₹ million) }\end{array}$ & $1,504.20$ & $1,504.20$ & & 306.87 & 306.87 & \\
\hline $\begin{array}{l}\text { Rural water supply and } \\
\text { irrigation (₹ million) }\end{array}$ & $9,590.52$ & $9,590.52$ & & 401.66 & 401.66 & \\
\hline Agriculture (₹ million) & $19,613.02$ & $5,883.91$ & $13,729.11$ & $2,497.30$ & 842.57 & $1,654.73$ \\
\hline Fishing (₹ million) & $6,047.00$ & 98.76 & $5,948.24$ & $2,139.00$ & 52.02 & $2,086.98$ \\
\hline $\begin{array}{l}\text { Total } \\
\text { (₹ million) }\end{array}$ & $79,807.95$ & $34,904.67$ & $44,903.28$ & $7,495.34$ & $2,510.49$ & $4,984.85$ \\
\hline $\begin{array}{l}\text { Total } \\
\text { (\$ million) }\end{array}$ & $1,140.11$ & $\begin{array}{r}498.64 \\
(44 \%)\end{array}$ & $\begin{array}{r}641.48 \\
(56 \%)\end{array}$ & 107.08 & $\begin{array}{l}35.86 \\
(33 \%)\end{array}$ & $\begin{array}{r}71.21 \\
(67 \%)\end{array}$ \\
\hline
\end{tabular}

Source: Author's calculations based on data in Government of Odisha, ADB, and World Bank (2013) and Government of Odisha (2018).

\section{B. Impacts on Businesses}

Besides households, extreme precipitation events affect businesses through damage to building structures, machinery, equipment, and inventory and disruptions to normal business activities. This section focuses on a primary survey of retail businesses carried out by the author in Mumbai (Patankar et al. 2012), a study conducted among SMEs in Chennai (Mercy Corps and Okapi 2016), and estimated losses suffered by artisans and SMEs after Cyclone Phailin in Puri district (Government of Odisha, ADB, and World Bank 2013).

\section{Mumbai}

To estimate the direct impacts of extreme rainfall on businesses after the extreme floods in July 2005, a primary survey was carried out among 627 randomly selected retail outlets operating from six floodprone wards. The impacts on retail businesses were estimated as damage costs for different categories, as used in Messner et al. (2007) and Kreibich et al. (2010): premises (physical structures), equipment 
(appliances and equipment), and material (products and raw materials). Table 10 presents the average damage cost (cost of repair or replacement of premises, equipment, and material) for each ward and for the entire dataset.

Most retail businesses operate from the ground floor of buildings or in single-story roadside structures. Hence, much of the damage cost involved repairing grounds and fencing, foundations, walls, windows, and doors. Businesses also reported damage to machines and tools, refrigerators, escalators, electrical switches, and wiring. Raw materials, inventory, and finished products also sustained extensive damage. Since retail businesses are unwilling to report annual turnover, and business size varies substantially across different types of retail businesses and outlets, it was not possible to estimate damage costs as a percentage of their revenues. However, most businesses (93\%) did not have flood insurance cover. Hence, they would have had to use their own resources to cover repairs and replacements.

Table 10: Damage Costs Faced by Typical Retail Businesses in Mumbai (₹)

\begin{tabular}{|c|c|c|c|c|c|c|c|}
\hline Item & F North & F South & H East & K East & LWard & P North & Total Average \\
\hline \multicolumn{8}{|l|}{ Premises } \\
\hline Grounds and fences & 14,500 & 35,000 & 67,000 & 16,000 & 95,000 & 28,700 & 48,000 \\
\hline Foundations & 10,000 & & 22,000 & 11,300 & & 60,000 & 15,500 \\
\hline Flooring & & & 13,500 & 10,500 & & & 11,500 \\
\hline Walls & 8,400 & 4,000 & 8,000 & 13,700 & 3,500 & 12,500 & 10,200 \\
\hline Windows & 7,000 & 3,000 & 6,000 & 13,800 & 5,000 & & 8,300 \\
\hline Doors & 7,500 & 39,000 & 8,000 & 7,000 & 7,000 & 7,900 & 10,000 \\
\hline \multicolumn{8}{|c|}{ Appliances and Equipment } \\
\hline $\begin{array}{l}\text { Communication } \\
\text { systems }\end{array}$ & 15,000 & & 10,000 & & 1,800 & & 7,000 \\
\hline Escalators & 8,000 & & 8,500 & 15,000 & 17,500 & & 10,900 \\
\hline Heating equipment & & & & 2,700 & 3,000 & & 2,800 \\
\hline $\begin{array}{l}\text { Air conditioning } \\
\text { equipment }\end{array}$ & & & & 11,000 & 1,700 & & 8,675 \\
\hline Refrigerators & 14,000 & 18,000 & 15,000 & 7,800 & 6,500 & 17,500 & 10,600 \\
\hline Electrical equipment & 10,500 & 8,800 & 16,000 & 7,000 & 15,000 & 5,500 & 10,500 \\
\hline Machines and tools & 11,500 & 24,000 & 19,000 & 14,000 & 22,000 & 14,400 & 17,000 \\
\hline \multicolumn{8}{|l|}{ Products } \\
\hline Finished products & 15,800 & 25,000 & 22,600 & 24,500 & 37,000 & 19,400 & 23,000 \\
\hline Raw material & 12,000 & 180,000 & 24,000 & 17,000 & 24,000 & & 40,000 \\
\hline $\begin{array}{l}\text { Partly assembled } \\
\text { products }\end{array}$ & 13,000 & 6,000 & 13,700 & 12,000 & 6,000 & & 11,600 \\
\hline Inventory & 28,000 & 9,000 & 21,800 & 6,000 & 11,000 & 10,000 & 19,300 \\
\hline
\end{tabular}

Source: Author's calculations based on primary data used in Patankar et al. 2012.

Besides repairing and replacing premises, equipment, and products, businesses incurred immediate expenses to cope with floodwaters entering their premises (Table 11). The recovery time for businesses in each ward was 1-16 days, with an average of 3-4 days. 
Table 11: Immediate Expenditure after Floods

(₹)

\begin{tabular}{|c|c|c|c|c|c|c|c|}
\hline Item & F North & F South & H East & K East & LWard & P North & Total Average \\
\hline $\begin{array}{c}\text { Disinfecting } \\
\text { premises }\end{array}$ & 10,000 & 18,000 & 25,000 & 14,800 & 80,000 & 23,000 & 34,000 \\
\hline $\begin{array}{r}\text { Flood rescue } \\
\text { operations }\end{array}$ & & & 7,800 & 2,500 & 26,500 & & 8,600 \\
\hline Removing debris & 4,600 & 6,000 & 7,800 & 5,500 & 16,000 & 26,400 & 12,700 \\
\hline $\begin{array}{l}\text { Alternative } \\
\text { operative costs }\end{array}$ & 6,000 & 6,700 & 10,000 & 4,000 & 11,000 & 12,500 & 9,000 \\
\hline $\begin{array}{l}\text { Emergency } \\
\text { expenditure }\end{array}$ & 11,500 & 10,600 & 24,000 & 31,000 & 140,000 & 70,000 & 69,000 \\
\hline Revenue loss & 100,000 & 15,500 & 20,600 & 42,000 & 84,500 & 39,000 & 60,000 \\
\hline Recovery time & $1-12$ days & $1-15$ days & $1-15$ days & $1-14$ days & $1-16$ days & $1-10$ days & $1-10$ days \\
\hline
\end{tabular}

Source: Author's calculations based on primary data used in Patankar et al. 2012.

\section{Chennai}

Incessant rains in November 2015 and extreme single-day rainfall on 2 December 2015 severely affected SMEs in Chennai. SMEs form an integral part of overall industrial growth in the state of Tamil Nadu. They span industries such as automobile components, electronics, textiles, leather, chemicals, and plastics for the domestic and international markets (Mercy Corps and Okapi 2016). The SME sector grew by 50\% during 2007-2014 in Chennai and nearby districts (Mercy Corps and Okapi 2016). However, these enterprises are acutely vulnerable because of their location in flood-prone areas.

In a survey after the December 2015 floods of businesses predominantly operating from industrial estates, Nurture Trust, in collaboration with Feedback Consulting and SRM University (Mercy Corps and Okapi 2016), calculated an average direct loss of ₹1.8 million $(\$ 20,000)$ per business. Medium-scale businesses (those with an annual turnover of less than ₹100 million) were the worst affected. Most losses were caused by damage to fixed assets such as physical infrastructure. Manufacturing industries with large quantities of these assets and heavy machinery suffered the most. Only $37 \%$ of businesses had insurance against natural calamities and only $50 \%$ of the insurance claimed for the reported damages was received.

To augment the findings of this study and understand the intangible damage such as loss of customer confidence and disruption of supply chains, semi-structured interviews of 35 business units were carried out in different flood-affected areas (Mercy Corps and Okapi 2016). The survey covered SMEs operating both within and outside industrial estates. Some of the key findings are highlighted in the following paragraphs.

Most surveyed firms suffered damage to buildings, equipment, and inventory. For two-thirds of those interviewed, damage to equipment was far greater than damage to buildings and inventory. Most of the building damage was from water seepage affecting floors or ceilings. Many firms also lost important work-related documents and even soft copies of documents were lost when electronic equipment, such as computers, were washed away. The cost of recovery of damaged equipment ranged from ₹25,000 to ₹25 million. Lacking funds to repair equipment, many businesses started staggered operations after 1-2 weeks. 
Businesses' locational choices were driven by advantages such as business potential, continuity, proximity to clients, accessibility of workers, presence of specific large industries, and ease of logistics. Exposure to natural hazards, such as floods, was not considered an important factor in the choice of location. Some businesses were aware of this risk but considered it easy to mitigate. The more cash-rich enterprises had invested in raising the floor level of their entire premises by a few feet to mitigate the flood risk.

Some business owners stated that they would not consider relocating from their present plant in the industrial estate even if a similar event were to happen again. They would rather invest in protecting their assets from floodwaters. However, a few firms stated that if they were to start a business after the extreme event, they would not choose the present location but would instead consider other options near Chennai.

Most businesses remained without electricity for an average of 13 days and without water supply for 12 days. For most businesses, solid waste and sewage issues were not resolved for more than 15 days. For some, it took a month or more. It took an average of 9 days to recover from waterlogging inside premises. Businesses on industrial estates had two coping mechanisms that those outside such estates lacked: reliable power supply and the ability to run their business in shifts. Hence, SMEs operating elsewhere stated that they would move to these estates, despite their flood-prone locations, if the opportunity arose.

Increased road heights were another major reason business premises flooded despite their raised floor levels. Many other locational factors that were beyond businesses' control, such as the state of the drainage network, encroachments, and improper desilting, contributed to flooding and impacted the businesses.

Limited or no access to financial capital amplified the impacts of the floods. Some SMEs had to sell their assets, close their business, and find wage employment elsewhere because of the lack of financial support after the December 2015 floods. Most smaller entities had invested their own money or borrowed from private sources to set up their business. They also typically had slim margins and limited supplier credit. These businesses' postflood losses were amplified by a lack of access to emergency funds and additional finance. With the shutdown of production, lack of inputs, and loss of clients, many firms reported significant financial distress and an inability to repay existing business loans. The extreme floods also exposed a very high reliance on informal financing channels, such as friends and moneylenders. Insurance payouts for those covered were very low and cases were left pending for months.

Postflood losses were higher for businesses that maintain a large inventory of raw materials (often for just-in-time services) and finished products. For those involved in global supply chains, shutting down production risked the loss of international clients. Most businesses that supplied local clients did not lose customers, although some that had to run production with partly repaired machinery lost clients because of the poor quality of the finished goods.

\section{Puri District}

Compared with Mumbai and Chennai, Puri district is largely rural, and besides agriculture, its only businesses are in the handloom and handicrafts sector and a few SMEs. The cyclone and floods affected artisan and weaver households by damaging their work shades, looms, and materials (Table 12). Average losses were estimated at ₹ 6,925 per artisan household and ₹ 5,000 per weaver household. 
Table 12: Damage Costs to Handloom and Handicrafts Businesses

\begin{tabular}{lrr}
\hline Handloom and Handicrafts & \multicolumn{1}{c}{ Total } & \multicolumn{1}{c}{ Puri } \\
\hline Artisans affected (number) & 1,564 & 722 \\
Work shades damaged (number) & 736 & 4 \\
Handicrafts losses (₹ million) & 42.00 & 5.00 \\
Loss per household (₹) & $26,854.22$ & $6,925.21$ \\
Weavers affected (number) & 501 & 12 \\
Work shades damaged (number) & 385 & 10 \\
Raw and finished product damaged (number) & 706 & 9 \\
Handloom losses (₹ million) & 5.00 & 0.06 \\
Loss per household (₹) & $9,980.04$ & $5,000.00$ \\
\hline
\end{tabular}

Source: Compiled from Government of Odisha, ADB, and World Bank. 2013.

SMEs losses included damage to buildings, plant and machinery, raw materials, and finished products (Table 13). Losses suffered by SMEs from Cyclone Phailin and floods in Puri district totaled ₹14.8 million, and the average loss per SME was ₹126,495.

Table 13: Damages Suffered by Small and Medium-Sized Enterprises

\begin{tabular}{lrr}
\hline Small and Medium-Sized Enterprises & Total & Puri \\
\hline Units affected (number) & 1,039 & 117 \\
Buildings damaged (₹ million) & 41.97 & 7.20 \\
Plant and machines damaged & 28.76 & 1.60 \\
(₹ million) & & \\
Raw material damaged (₹ million) & 43.58 & 6.00 \\
Finished products damaged (₹ million) & 20.75 & 0.00 \\
Total loss (₹ million) & 135.06 & 14.80 \\
Per unit loss (₹) & $129,990.38$ & $126,495.73$ \\
\hline
\end{tabular}

Source: Compiled from Government of Odisha, ADB, and World Bank. 2013.

\section{SUMMARY AND CONCLUSION}

Floods account for more than half of climate-related disasters in India and cause damages of $\$ 54.63$ billion during 1990-2017. Global warming and climate change are expected to increase the frequency and intensity of these disasters. Mean annual rainfall and extreme single-day rainfall events are also projected to increase in frequency and intensity. The scale of the impacts of these extreme events on people and ecological systems depends on vulnerability and exposure. Calculations of losses are usually lower-bound estimates because of the presence of a large informal economy and the difficulty of monetizing indirect impacts. Impacts are further intensified by socioeconomic factors such as increasing population, rapid urbanization, infrastructure expansion in high-risk zones, and the large number of people living in informal settlements in poor and destitute conditions. These factors underscore the need to characterize and analyze the impacts of extreme precipitation events on different actors in the economy and society and to formulate policies and plans to mitigate them. 
To understand the impacts of extreme rainfall events on households and businesses, the study chose three diverse cases: Mumbai, Chennai, and Puri district. All three locations faced devastating extreme rainfall events and offer rich insights into the asset exposure and direct and indirect impacts on poor urban and rural households, small businesses, and farming communities. The hybrid data, field-level and secondary, used to analyze these impacts provide a multidimensional view with quantitative estimates of impacts and qualitative insights into devastation and distress, usually not captured during routine damage assessments.

The findings of primary surveys in Mumbai and Chennai and government damage assessment reports in Puri district were examined to estimate direct and indirect impacts of extreme single-day rainfall events on households, retail businesses and SMEs in the three locations. The main findings are summarized below.

Poorer households are more vulnerable. Poorer families are more vulnerable to extreme events and floods because of their low incomes, poor-quality housing, and location in informal settlements in low-lying and flood-prone areas. Their main investments, including their house and household assets, are at risk from flood-related damage and destruction. During the extreme floods of July 2005, families living below the poverty line in Mumbai faced damage costs amounting to 1,480\% of the average monthly income of this socioeconomic class. In Chennai and Puri district, extreme floods washed away or partly damaged the houses of poor and migrant families.

Direct and indirect impacts on households. The types of impacts can typically be classified as damage to housing structures (floor, roof, walls); households assets (provisions, furniture, documents); appliances (lights, fans, refrigerator, washing machine); vehicles (bicycles, motorbikes); and work tools (carpentry tools, sewing machines). Although poor households face lower damage costs in absolute terms because they own so little, in relation to their earnings their damage costs are higher than those of better-off families. Overall, flood-affected households experienced damage to assets in which their life savings are invested (houses) or on which their livelihood depends (work tools, livestock). Extreme events therefore threaten the critical asset base of poor families. Households also had to cope with indirect impacts of floods, such as shortages of food, water, and fuel, and disruption of services. Workdays and even jobs were lost after the floods. Therefore, people faced loss of assets, livelihood, and access to basic services with obvious financial implications over the short to medium term to rebuild their lives and restore their assets to preflood levels.

Compensation and social protection are partial. In Mumbai and Chennai, the government offered some households a fixed amount as compensation to assist with immediate needs such as food and clothing. However, this amounted to less than $10 \%$ of total losses suffered by households across different socioeconomic strata. Many households, such as migrant workers in Chennai or families who had lost their documents and could not prove their identity or place of residence, were excluded as this made them ineligible for compensation. In Puri district, if compensation had been offered under the new notification of central and State Disaster Response Funds, it would have been inadequate to rebuild lives. Families that have limited resources and lack access to compensation mechanisms or government social protection had to use their savings or borrow from informal sources to rebuild their lives. This pushed them into indebtedness and poverty, negating the gains made by poverty reduction programs.

Insurance coverage is low. Penetration levels of general insurance are dismally low in India. More than $90 \%$ of the affected families had no insurance of any kind, let alone property or flood 
insurance. Even when families opted for insurance, claim settlements were lengthy, time consuming, and generally did not cover the full extent of the losses.

Impacts on small businesses. Impacts for retail businesses and SMEs can be classified as damage to premises (physical structure, flooring, roof, doors, and windows), equipment (air conditioning, heating, electrical and communication systems), and material (finished products, raw material, inventory). Most of the damage cost related to physical structure. Losses of finished products, inventory, and raw materials were also extensive. Besides the cost of damage, businesses also had to cover the immediate expenses of cleaning their premises, restarting operations, or temporarily moving production elsewhere. Overall, small businesses were more vulnerable to flood impacts than their larger counterparts because of their more limited technical and financial capacity and the absence of effective business continuity plans. They took longer to recover and lost customer confidence as a result. Businesses had to use their funds or borrow to build back to preflood levels.

Compensation and insurance. None of the businesses in the three locations studied reported receiving government compensation for their losses. As profit-making ventures, they may have been left to fend for themselves using their own resources. A few SMEs that had opted for flood insurance received less than the claimed amount after months of delay. Thus, compensation and insurance did not help businesses cope with flood impacts and rebuild.

Business continuity. After the Mumbai floods, business recovery time averaged 3-4 days, with some taking 1-2 weeks. In Chennai, where waterlogging affected many areas for a long time, businesses began staggered operations after 1-2 weeks. SMEs were without power, water, and other basic services for 10-15 days, impacting business continuity. As the losses from floods were unexpected, businesses took a long time to recover. Many could not repay loans taken from financial institutions. Loss of credit and clients increased their distress, and some businesses sold their assets and closed operations.

Besides the assessment of direct and indirect impacts, households shared experiences about rescue and relief operations in the aftermath of floods. These experiences demonstrate why wellintentioned efforts may not reach the beneficiaries. In Chennai, for example, rescue operations and relief material only reached houses located along the roadside. Those who lived in interior parts of affected areas received nothing. When food packets and other material were airdropped, they were scattered and people could not reach or use them. In Chennai and Mumbai, people did not receive any flood warning, and by the time they realized the intensity of rainfall, the floodwaters had already entered their homes or flooded access roads. Even when compensation was offered, government officials declared many affected households ineligible because of their migrant status or other reasons. In some areas, people who had been relocated from other hazard-prone areas in the past were affected once again in the supposedly safer areas. Experiences like this raise many questions about the quality of rescue, relief, resettlement, and rehabilitation processes.

To conclude, insights offered by the assessment and characterization of flood impacts on households and businesses help us understand and appreciate how extreme events affect people and the assets they have built as financial protection or to improve their lives. The findings from this exercise also raise important questions regarding the long-term economic impacts of extreme events on poor families and the need for a protective social safety net to prevent their downward spiral into poverty and debt. Adaptation policies and plans should be designed to protect poor and vulnerable people from risks associated with extreme events. This will help mainstream adaptation into larger development and poverty reduction policies and programs. 


\section{REFERENCES}

Annez, Patricia, Alain Bertaud, Bimal Patel, and Vidyadhar Phatak. 2010. "Working with the Market: Approach to Reducing Urban Slums in India, Policy Research.” World Bank Working Paper 5475.

Brouwer, Roy, Sonia Atker, Luke Brander, and Enamul Haque. 2007. "Socioeconomic Vulnerability and Adaptation to Environmental Risk: A Case Study of Climate Change and Flooding in Bangladesh." Risk Analysis 27 (2): 313-26.

Citizen Consumer and Civic Action Group (CAG). 2016. Sample Survey of Losses Sustained during Chennai Floods: With Special Reference to Losses and Damages of Possessions, Loss of Workdays and Damage to Homes. http://tnlabour.in/wp-content/uploads/2016/01/Report-of-Survey-ofLosses-Sustained-during-Chennai-Floods_20160113.pdf.

EM-DAT. 2018. The International Disasters Database. https://www.emdat.be/.

DesInventar. 2018. Disaster Information Management System. https://www.desinventar.net/.

Goswami, Bhupendra Nath, V. Venugopal, Debasis Sengupta, M.S. Madhusoodanan, and Prince K. Xavier. 2006. "Increasing Trend of Extreme Rain Events over India in a Warming Environment.” Science 314 (5804): 1442-57.

Government of India, Ministry of Finance. 2018. Economic Survey of India 2017-18. Delhi. http://mofapp.nic.in:8080/economicsurvey/.

Government of India, Planning Commission. 2013. Press Note on Poverty Estimates 2011-12. http://planningcommission.nic.in/news/pre_pov2307.pdf.

Government of Odisha. 2018. Puri District Disaster Management Plan 2017-18, Vol. I. Bhubaneswar.

Government of Odisha, Asian Development Bank, and World Bank. 2013. India Cyclone Phailin in Odisha: Rapid Damage and Needs Assessment Report. Bhubaneswar.

Government of Tamil Nadu. 2018. Chennai District Profile 2017. Chennai. https://chennai.nic.in/aboutdistrict/district-profile/.

Greater Chennai Corporation (GCC). 2017. City Disaster Management Plan 2017. http://www.chennaicorporation.gov.in/NorthMonSoon2017/cdmcb.pdf, Greater Chennai Corporation.

Hallegatte, Stephane, Nicola Ranger, Olivier Mestre, Patrice Dumas, Jan Corfee-Morlot, Celine Herweijer, and Robert Muir Wood. 2011. "Assessing Climate Change Impacts, Sea Level Rise and Storm Surge Risk in Port Cities: A Case Study on Copenhagen." Climatic Change 104: 113-7.

Indian Space Research Organisation (ISRO). 2015. Chennai Floods 2015: A Satellite and Field Based Assessment Study. Hyderabad: National Remote Sensing Centre, ISRO.

Intergovernmental Panel on Climate Change (IPCC). 2012. Managing the Risks of Extreme Events and Disasters to Advance Climate Change Adaptation: Special Report of the Intergovernmental Panel on Climate Change. Cambridge University Press. 
Khandlhela, Masingita, and Julian May. 2006. "Poverty, Vulnerability and the Impact of Flooding in Limpopo Province, South Africa." Natural Hazards 39 (2): 275-87.

Kreibich, Heidi, Isabel Seifert, Bruno Merz, and Annegret H. Thieken. 2010. "Development of FLEMOcs: A New Model for the Estimation of Flood Losses in the Commercial Sector." Hydrological Sciences Journal, 58 (8) 1302-14.

Mercy Corps and Okapi. 2016. Transforming Chennai: A Research Report on Building Micro, Small and Medium Enterprise Resilience to Water-Related Environmental Change. https://www.mercycorps.org/sites/default/files/Transforming_Chennai_Okapi_Mercy_Corps.pdf.

Merz, Bruno, Heidi Kreibich, Reimund Schwarze, and Annegret Thieken. 2010. "Assessment of Economic Flood Damage.” Natural Hazards and Earth System Sciences 10: 1697-1724.

Messner, Frank, Edmund Penning-Rowsell, Colin Green, Volker Meyer, Sylvia Tunstall, and Anne van der Veen. 2007. Evaluating Flood Damages: Guidance and Recommendations on Principals and Methods. http://www.floodsite.net/html/partner_area/project_docs/T09_06_01_Flood_damage_guidelin es_d9_1_v2_2_p44.pdf.

Munich Re. 2018. Natural Catastrophe Statistics online: The New NatCatSERVICE Analysis Tool. https://www.munichre.com/en/reinsurance/business/non-life/natcatservice/index.html.

Municipal Corporation of Greater Mumbai (MCGM). 2006. Fact Finding Committee on Mumbai Floods, Final Report, Volume I, March 2006. Mumbai. 2018. Flood Preparedness Guidelines 2018. Mumbai.

National Institute of Disaster Management (NIDM). 2014. Proceedings of National Workshop on Phailin Cyclone 2013: Lessons Learned. Delhi: Ministry of Home Affairs, Government of India.

National Sample Survey Office (NSSO). 2010. Housing Condition and Amenities in India 2008-2009. Delhi: Ministry of Statistics and Programme Implementation, Government of India.

Patankar, Archana. 2015. "The Exposure, Vulnerability, and Ability to Respond of Poor Households to Recurrent Floods in Mumbai.” World Bank Policy Research Working Paper 7481.

Patankar, Archana, and Anand Patwardhan. 2015. Estimating the Uninsured Losses due to Extreme Weather Events and Implications for Informal Sector Vulnerability: A Case Study of Mumbai, India, Natural Hazards. Springer. http://link.springer.com/article/10.1007/s11069-015-1968-3.

Patankar, Archana, Anand Patwardhan, Wijitbusaba Ann Marome, and Emma Porio. 2012. Enhancing Adaptation to Climate Change by Integrating Climate Risk into Long-Term Development Plans and Disaster Management. APN E-Lib. http://www.apn-gcr.org/resources/items/show/1572.

Piya, Luni, Keshav Lall Maharjan, and Niraj Prakash Joshi. 2012. Vulnerability of Rural Households to Climate Change and extremes: Analysis of Chepang Households in the Mid-Hills of Nepal. Paper presented at the International Association of Agricultural Economists Triennial Conference, Brazil. 
Rajeevan, M, Jyoti Bhate, and Ashok K. Jaswal. 2008. "Analysis of Variability and Trends of Extreme Rainfall Events over India Using 104 Years of Gridded Daily Rainfall Data." Geophysical Research Letters 35.

Schaer, Caroline, and Archana Patankar. 2018. "Promoting Private Sector Engagement in Climate Change Adaptation and Flood Resilience: A Case Study of Innovative Approaches Applied by MSMEs in Mumbai, India." In Theory and Practice of Climate Adaptation, Climate Change Management edited by F. Alves, W. Leal Filho, and U. Azeiteiro, 175-91. Cham: Springer.

United Nations. 2016. The World's Cities in 2016: Data booklet. New York: Population Division, Department of Economic and Social Affairs, United Nations.

United Nations Office for Disaster Risk Reduction (UNDRR). 2018. "Odisha Profile, Deslnventar." https://www.desinventar.net/DesInventar/profiletab.jsp? countrycode=019.

Walch, Colin. 2018. "Adaptive Governance in the Developing World: Disaster Risk Reduction in the State of Odisha, India." Climate and Development 11 (3): 238-52.

Warner, Koko, and Kees van der Geest. 2013. "Loss and Damage from Climate Change: Local-Level Evidence from Nine Vulnerable Countries." International Journal of Global Warming 5 (4): 367-86.

World Bank. 2004. "Understanding the Economic and Financial Impacts of Natural Disasters." Disaster Risk Management Series 4. Washington, DC: World Bank. 


\section{Impacts of Natural Disasters on Households and Small Businesses in India}

This paper characterizes impacts of extreme precipitation events at the micro level on vulnerable households and small and medium-sized enterprises in three locations in India: Mumbai, Chennai, and Puri District. Flood impact analysis provides a multidimensional view with quantitative damage estimates and qualitative insights into the devastation and distress caused. It also offers critical insights into the heterogeneity of flood impacts and their implications for poverty.

\section{About the Asian Development Bank}

ADB is committed to achieving a prosperous, inclusive, resilient, and sustainable Asia and the Pacific, while sustaining its efforts to eradicate extreme poverty. Established in 1966, it is owned by 68 members -49 from the region. Its main instruments for helping its developing member countries are policy dialogue, loans, equity investments, guarantees, grants, and technical assistance. 